\title{
Eksplorasi Disain Ventilasi Ruang Kuliah Untuk Mencapai Kenyamanan Termal
}

\author{
Qurrotul A'yun, Puspita Cahya Wati, Muhammad Choirul Khafidz \\ Prodi Arsitektur Universitas Islam Negeri Sunan Ampel, Surabaya, Indonesia \\ qurrotul_ayun@uinsby.ac.id, puspitacahyawati@gmail.com,cooy.ipa4@gmail.com \\ doi.org/10.29080/eija.v4i2.445
}

\begin{abstract}
Thermal comfort is an important factor to support indoor human activity. To maximize the thermal comfort without damaging the environment, the potential of wind can be created through cross ventilation system. Ventilation can be a good medium as an air diverter, if we pay attention to 3 (three) aspects, that is in size, shape, and position of ventilation. The study aimed to explore the best ventilation design to achieve indoor thermal comfort, especially in classrooms. The research use descriptive quantitative method to produce a design recommendation, which is followed by data validation using ecotect software. Classrooms at the Ushuluddin Faculty UIN Sunan Ampel were chosen to be case studies. The result show that cross ventilation through big windows with vertically pivoted ventilation model is the most effective ventilation design. The model could maximize airflow until $75 \%$, and make the room $1,4-2,7^{\circ} \mathrm{C}$ cooler.
\end{abstract}

Keywords: cross ventilation, ecotect, natural ventilation, thermal comfort, ventilation design

Abstrak: Kenyamanan termal menjadi faktor penting dalam menunjang efektifitas kinerja di dalam ruang. Untuk memaksimalkan kenyamanan termal tanpa merusak lingkungan, potensi angin dapat dimanfaatkan melalui sistem ventilasi silang. Ventilasi silang dapat menjadi media yang baik sebagai pengalir udara, jika memperhatikan 3 (tiga) aspek, yaitu ukuran, bentuk, dan posisi ventilasi. Tujuan dari penelitian ini adalah mengeksplorasi desain ventilasi terbaik untuk mencapai kenyamanan termal yang dimaksud, khususnya pada ruang-ruang perkuliahan. Metode penelitian yang digunakan adalah deskriprif kuantitatif untuk menghasilkan sebuah rekomendasi desain, yang diikuti dengan validasi data menggunakan software ecotect. Ruang-ruang perkuliahan di Fakultas Ushuluddin UIN Sunan Ampel dipilih untuk menjadi studi kasus. Hasil penelitian menunjukkan bahwa ventilasi silang melalui jendela besar berjenis vertically pivoted merupakan ventilasi yang paling efektif untuk dipakai di ruang-ruang perkuliahan Fakultas Ushuluddin. Model ini dapat memaksimalkan aliran udara hingga $75 \%$, dan membuat ruangan $1,4-2,7^{\circ} \mathrm{C}$ lebih sejuk.

Kata Kunci: ventilasi silang, ecotect, penghawaan alami, kenyamanan termal, disain ventilasi

\section{PENDAHULUAN}

Ruang kelas merupakan bagian yang tidak terpisahkan di dalam kegiatan belajar di universitas. Louisell dalam Winaputra (2008) mengungkapkan, setidaknya ada 5 (lima) komponen yang dapat menunjang pembelajaran yang efektif, yaitu kenyamanan, kebebasan pandangan, kemudahan akses, fleksibilitas dan keindahan. Menurut Mendell (2005), kenyamanan, secara spesifik kenyamanan termal, menjadi salah satu persyaratan agar pengguna dapat beraktivitas dengan baik di dalam ruangan. Dengan terciptanya kenyamanan termal di dalam ruang kelas, maka mahasiswa akan dapat lebih produktif dalam belajar dan secara tidak langsung mampu meningkatkan prestasi belajar mereka.

Gratia (2004) dalam tulisannya menyatakan bahwa ventilasi menjadi salah satu alat pengalir udara yang juga berfungsi sebagai alat untuk mencapai kenyamanan termal. Bagian dalam ruangan setidaknya harus memiliki saluran masuk (inlet) dan saluran keluar (outlet). Mediastika (2004) pun menjelaskan bahwa posisi inlet dan outlet ini, memiliki pengaruh besar pada tingkat penyebaran udara di dalam ruangan. Varian ventilasi yang dipilih juga turut menentukan kuantitas aliran ke dalam ruang. Dengan demikian untuk mencapai kenyamanan termal melalui ventilasi harus memperhatikan 3 (tiga) faktor, seperti ukuran, bentuk, posisi dari inlet dan outlet. (Mediastika, 2004)

Fakultas Ushuluddin merupakan satu dari sembilan fakultas yang ada di Universitas Islam Negeri Sunan Ampel. Bangunan ruang kelas di Fakultas Ushuluddin ini berbentuk konfigurasi huruf $U$ (gambar 1) dan menghadap ke timur serta orientasi bangunan menghadap ke arah utara - selatan. 
Penelitian ini hanya fokus pada ruang kelas yang ada di sisi timur karena merupakan bagian yang paling terkena panas matahari dan mempengaruhi kenyamanan ruang di dalamnya.

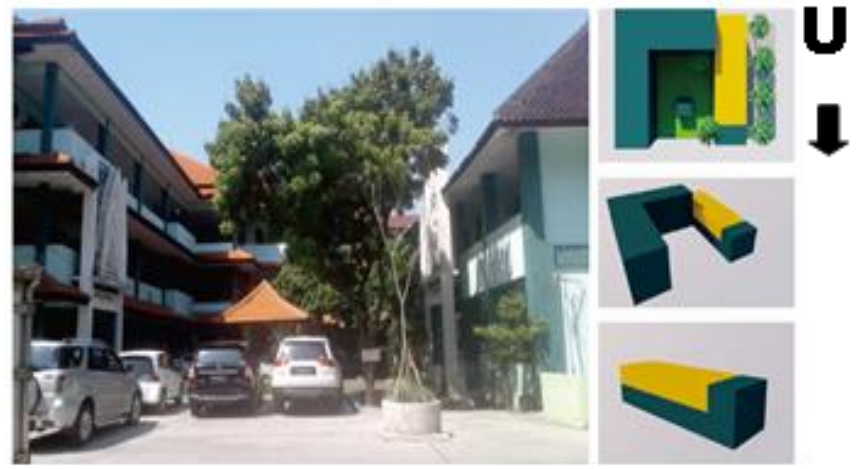

Gambar 1. Suasana dan posisi gedung Fakultas Ushuluddin (sumber: dokumentasi dan sketsa peneliti, 2018)

Adapun tujuan penelitian ini adalah untuk mengeksplorasi rekomendasi disain ventilasi yang dapat mewujudkan kenyamanan termal melalui serangkaian analisis dengan tanpa harus mengubah struktur eksisting bangunan yang sudah berdiri.

\section{METODE PENELITIAN}

Penelitian ini merupakan penelitian deskriptif kuantitatif dengan variabel yang berperan dalam aspek-aspek ini terdiri dari: ukuran ventilasi, bentuk ventilasi, dan posisi ventilasi sebagai variabel bebas, dan suhu ruangan sebagai variabel terikatnya. Data terkait ke empat variabel diperoleh dari hasil observasi langsung terhadap tiga tipe ruangan kelas yang menjadi obyek kajian. Data yang dikumpulkan kemudian di eksplorasi peneliti untuk memperoleh detail rekomendasi rancangan arsitektur.

Peneliti menggunakan piranti lunak ecotect untuk menganalisis kenyamanan termal pada setiap rekomendasi disain yang dihasilkan sekaligus memperoleh tingkat signifikansi pengaruh setiap rekomendasi disain terhadap variabel suhu ruangan. Tersedianya fitur data iklim lokal dalam piranti lunak ecotect menjadi pertimbangan dalam pemilihan alat analis mengingat adanya variabel iklim lingkungan yang tidak dapat diukur secara kuantitatif.

\section{HASIL DAN PEMBAHASAN}

\subsection{Kondisi eksisting kelas}

Berdasarkan hasil observasi diketahui bahwa gedung Fakultas Ushuluddin hanya memiliki ruang kelas di lantai 2 dengan tiga ruangan kelas dan dikatagorikan dalam tiga tipe yang berbeda (lihat gambar 2). Uraian berikut akan membahas mengenai kondisi setiap ruang kelas berdasarkan pada variabel variabelnya.

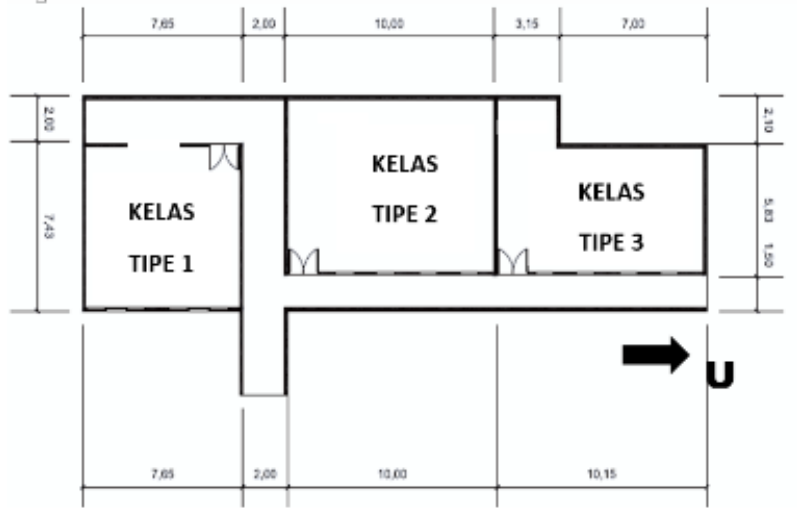

Gambar 2 . Tipe ruang kelas di Fakultas Ushuluddin (Sumber: hasil analisis, 2018)

\section{Kelas Tipe 1}

Kelas Tipe 1 memiliki luas lantai sebesar $56.8 \mathrm{~m}^{2}$ dan menghadap ke arah utara. Ruangan ini cenderung kurang mendapat cahaya alami karena berada di sudut bangunan serta terhalang oleh gedung yang lain, sehingga sumber penerangan cenderung mengandalkan kepada pencahayaan buatan (gambar 3).

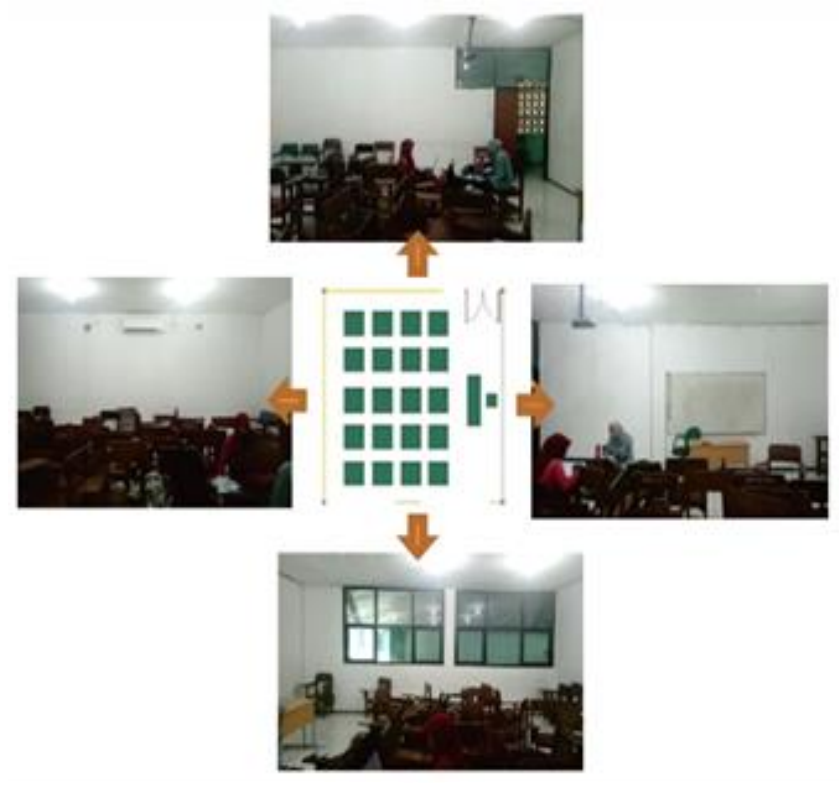

Gambar 3. Kondisi eksisting ruang kelas tipe 1 (sumber: dokumentasi peneliti, 2018)

Jika pintu ruangan ini dalam posisi tertutup, sistem ventilasi silang tidak akan berlangsung dengan baik karena ventilasi hanya berada di satu sisi, yakni disisi timur. Ventilasi yang ada di sisi timur tersebut, terdiri atas kombinasi dari tiga jenis ventilasi yaitu jalousie, fixed dan casemet top-hung type, yang berjumlah dua modul dengan ukuran ventilasi sebesar $0,9 \mathrm{~m} \times 0,9 \mathrm{~m}$ atau seluas $0,81 \mathrm{~m}^{2}$ untuk casemet top-hung type (lihat gambar 4 dan 5). 


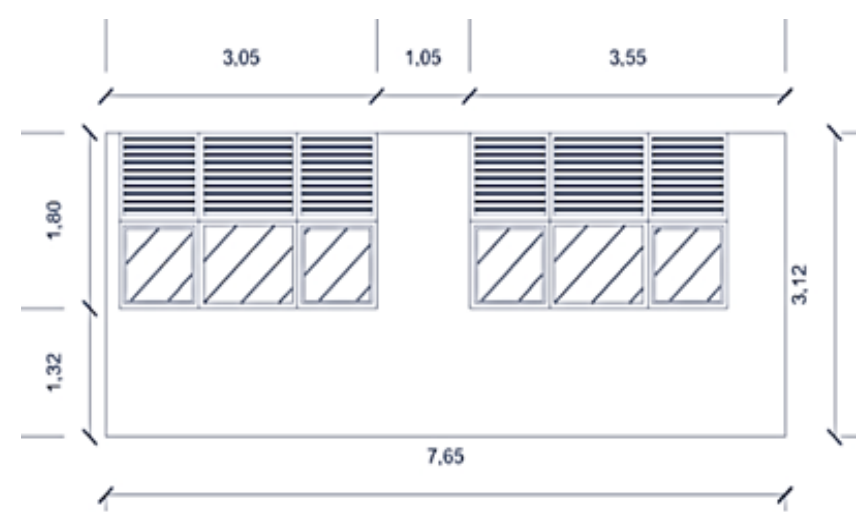

Gambar 4. Posisi ventilasi di ruang kelas Tipe 1 (sumber: hasil analisis, 2018)

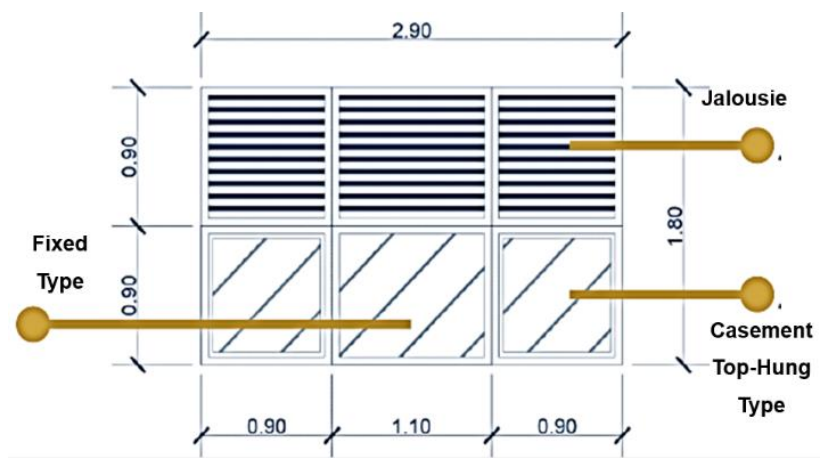

Gambar 5. Bentuk dan dimensi ventilasi di ruang kelas Tipe 1 (sumber: hasil analisis, 2018).

Lechner (2014) mengatakan bahwa sebuah ruangan idealnya memiliki minimal $10 \%$ dari luas lantai. Maka untuk kondisi ruang kelas Tipe 1, luas ideal ventilasi ruang kelas Tipe 1 adalah $10 \%$ dari $56,8 \mathrm{~m}^{2}$ atau sama dengan $5,68 \mathrm{~m}^{2}$. Sedangkan jumlah ventilasi ideal didapatkan dari hasil pembagian luas ventilasi ideal dengan luas ventilasi eksisting. Sehingga jumlah ventilasi ideal ruang kelas Tipe 1 dapat dihitung sebagai berikut:

\section{$5.68 \mathrm{~m} 2: 0,81 \mathrm{~m} 2=7$ unit ventilasi jenis casemet top-hung type}

Dari hasil perhitungan terlihat bahwa dengan kondisi eksisting ruangan hanya terdiri dari 4 unit ventilasi, ruangan kelas ini masih kekurangan minimal 3 unit ventilasi untuk mencapai kondisi ideal.

\section{Kelas Tipe 2}

Berbeda dengan ruang kelas Tipe 2, maka ruang berukuran $78.3 \mathrm{~m}^{2}$ ini justru menghadap ke arah selatan, dan mendapatkan cukup pencahayaan alami, sebab tidak ada penghalang apapun bagi masuknya cahaya matahari ke dalam ruangan (gambar 6). Di ruangan ini sistem ventilasi silang juga tidak bisa terjadi jika pintu dalam kondisi tertutup, karena ventilasi hanya berada di sisi timur bangunan. Namun di sisi timur juga terdapat modul ventilasi yang merupakan kombinasi dari 3 jenis sekaligus yakni jalousie, fixed dan casemet top-hung type, yang berjumlah dua modul dengan luasan $0,81 \mathrm{~m}^{2}$ (gambar 7 ).

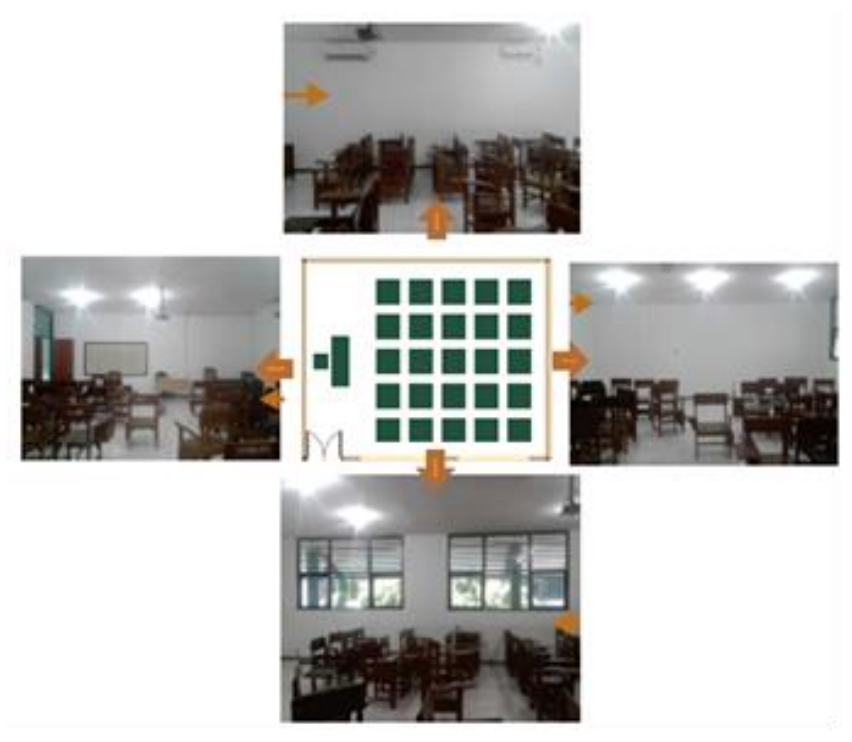

Gambar 6. Kondisi eksisting ruang kelas Tipe 2 (sumber: dokumentasi peneliti, 2018)

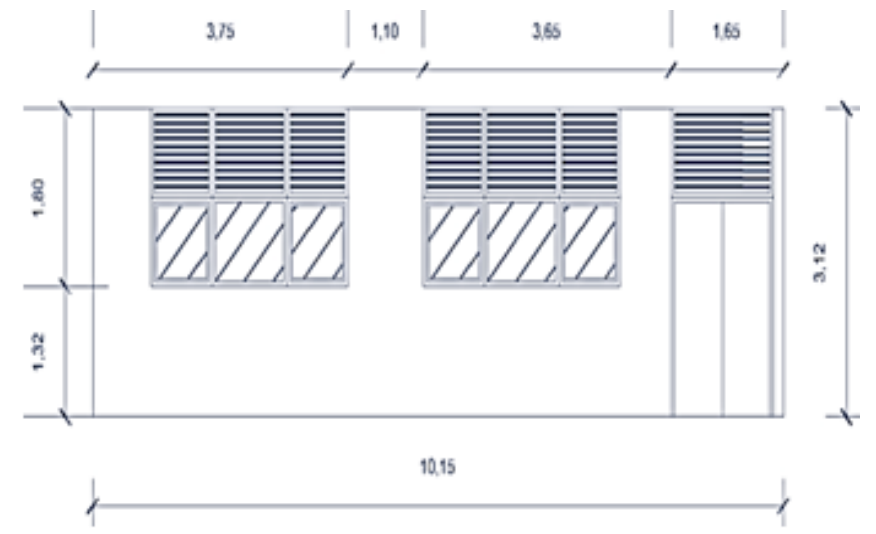

Gambar 7. Posisi ventilasi di ruang kelas Tipe 2 (sumber: hasil analisis, 2018)

Detail modulasi ukuran ventilasi di ruang kelas tipe 2 memiliki ukuran yang sama dengan ventilasi di ruang kelas Tipe 1, maka luasan ventilasi ideal di ruangan Tipe 2 menurut teori Lenchner (2014) adalah sebesar $10 \%$ dari luas ruangan atau sebesar $7.83 \mathrm{~m}^{2}$. Sedangkan untuk jumlah ventilasi ruang kelas tipe 2 adalah:

\section{$7.83 \mathrm{~m} 2: 0,81 \mathrm{~m} 2=10$ unit ventilasi jenis casemet top-hung type}

Dari hasil perhitungan terlihat bahwa dengan kondisi eksisting ruangan hanya terdiri dari 4 unit ventilasi, ruangan kelas ini masih kekurangan minimal 6 unit ventilasi untuk mencapai kondisi ideal.

\section{Kelas Tipe 3}

Ruang kelas Tipe 3, memiliki kondisi yang sama dengan ruang kelas Tipe 2 terkait dengan arah hadapnya, posisi dari ventilasi serta ukuran ventilasinya. Perbedaan hanya terletak pada dimensi ruang kelas, dimana ruang kelas Tipe 3 memiliki luasan sebesar $65.8 \mathrm{~m}^{2}$ (gambar 8 ). 

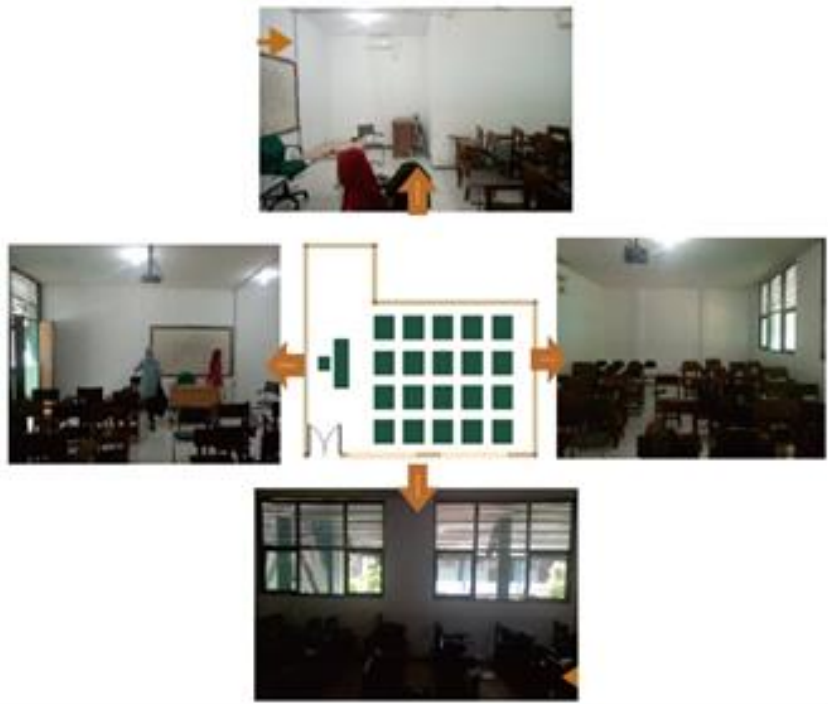

Gambar 8. Kondisi eksisting ruang kelas tipe 3 (sumber: dokumentasi peneliti, 2018)

\section{Suhu ruangan}

Suhu dari ketiga ruangan diukur pada minggu ke-3 di bulan Juni 2018 pada tiga waktu yang berbeda, yakni pagi, siang dan sore hari. Hasil pengukuran suhu dapat di lihat pada tabel 1.

Tabel 1. Hasil pengukuran suhu ruang kelas

\begin{tabular}{ccccc}
\hline \multirow{2}{*}{$\begin{array}{c}\text { Ruang } \\
\text { kelas }\end{array}$} & \multicolumn{4}{c}{ Waktu dan suhu ruangan $\left({ }^{\circ} \mathrm{C}\right)$} \\
\cline { 2 - 5 } & pagi & siang & sore & rata-rata \\
\hline Tipe 1 & 33,8 & 30,8 & 31,2 & 32 \\
Tipe 2 & 30,0 & 31,2 & 30,9 & 30,7 \\
Tipe 3 & 30,0 & 31,2 & 30,9 & 30,7 \\
\hline
\end{tabular}

Sumber: hasil analisis (2018)

Dari tabel 1 menunjukkan bahwa suhu dari tiga ruang kelas berkisar antara $30,7^{\circ} \mathrm{C}$ sampai dengan $32^{\circ} \mathrm{C}$, diatas standar kenyamanan termal maksimum di daerah tropis, yaitu $27,1{ }^{\circ} \mathrm{C}$ (Badan Standarisasi Nasional, 2001). Oleh karena itu, suhu ruang kelas eksisting saat ini, tentu masih belum dapat dikatakan nyaman secara termal.

\subsection{Rekomendasi disain terhadap variabel bebas}

Rekomendasi disain akan disarankan sesuai dengan variabel bebas penelitian, yaitu rekomendasi terhadap ukuran ventilasi, bentuk ventilasi serta posisi ventilasi. Setiap rekomendasi dari variabel-variabel bebas tersebut akan mempengaruhi suhu ruangan sebagai variabel terikatnya.

Menurut Dora (2011), dengan memperbesar dimensi ventilasi maka secara otomatis akan turut memperbesar area masuk untuk terjadinya pertukaran udara. Idealnya ukuran ventilasi berkisar 40 s.d $80 \%$ dari total luas dinding ruangan. Maka dari itu, ukuran ventilasi di setiap ruang kelas akan direkomendasikan diperbesar ukurannya hingga dua kali lipat.
Terkait bentuk ventilasi, Beckett dalam Latifah (2013), mengatakan ada empat jenis jendela ventilasi yang dapat memaksimalkan aliran udara di dalam ruangan, hingga di atas $50 \%$. Ke empat jenis ventilasi tersebut adalah jenis casement side-hung, casement top hung, horizontal pivoted and vertically pivoted (lihat gambar 9). Akan tetapi jenis ventilasi yang paling cocok untuk ventilasi besar adalah jenis vertically pivoted. Oleh karena itu, model ini akan dikembangkan sebagai rekomendasi disain.
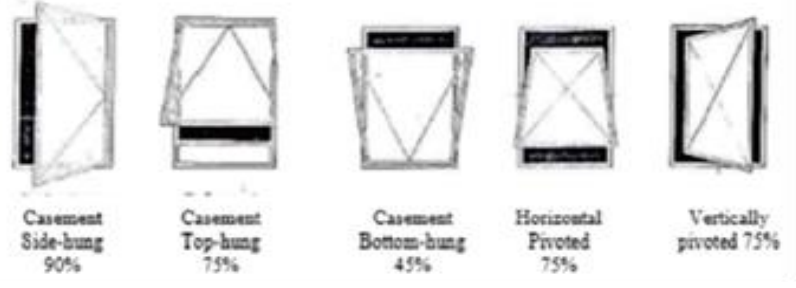

Gambar 9. Empat jenis tipe ventilasi (sumber : Beckett dalam Latifah, 2013)

Selanjutnya untuk posisi ventilasi, untuk memaksimalkan pengaliran udara melalui sistem cross ventilation maka hendaknya antara ventilasi masuk (inlet) dan ventilasi keluar (outlet) diletakkan secara berseberangan, seperti yang diilustrasikan pada gambar 10.
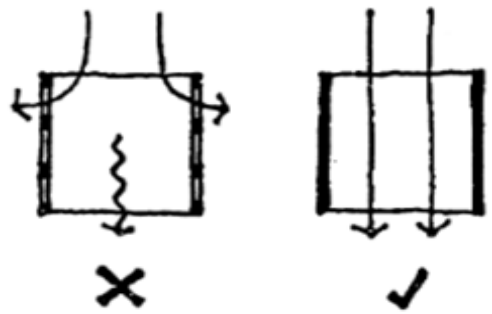

Gambar 10. Posisi penempatan inlet dan outlet ventilasi (sumber: Tantasavasdi, 2001)

Dalam pengaliran udara ke dalam ruangan pun perlu memperhatikan pemaksimalan sebaran udara ke seluruh penjuru ruangan. Untuk itu ventilasi masuk (inlet) harus pula dibuat dengan ukuran yang lebih besar daripada ventilasi keluar (outlet), seperti yang diilustrasikan pada gambar 11 .
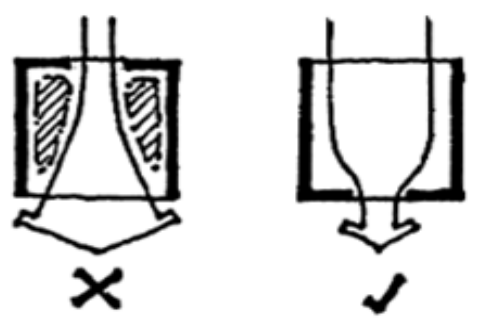

Gambar 11. Perbandingan ukuran inlet dan outlet ventilasi (sumber: Tantasavasdi, 2001)

Ketiga item rekomendasi tersebut menjadi dasar perancangan detail rekomendasi disain ventilasi pada tiap tipe kelas. 


\subsection{Rekomendasi disain ruang kelas}

\section{Kelas Tipe 1}

Pada kondisi eksistingnya, ventilasi hanya terdapat pada sisi bagian timur dari ruangan saja. Untuk menciptakan sistem ventilasi silang, ventilasi juga akan ditambahkan pada sisi bagian barat. Sisi timur akan menjadi ventilasi inlet dan sisi barat menjadi ventilasi outlet. Ukuran inlet akan diperbesar untuk menangkap angin yang datang dari sisi timur, yang selanjutnya diarahkan ke sisi barat, yang terhubung dengan lubang-lubang ventilasi dalam bentuk rooster. Untuk memaksimalkan angin yang masuk ke dalam ruangan hingga mencapai $75 \%$, maka jendela jenis vertically pivoted akan digunakan pada bagian inlet, sedangkan pada outlet akan dipasang jendela geser (gambar 12)

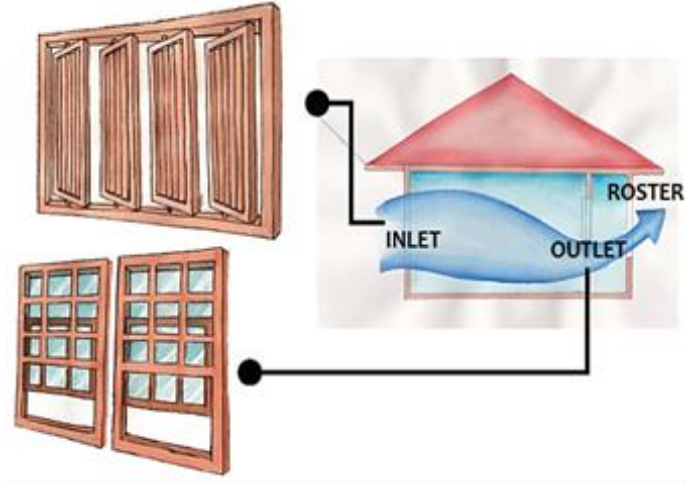

Gambar 12. Ilustrasi rekomendasi disain ventilasi silang di ruang kelas Tipe 1 (sumber: hasil analisis, 2018)

\section{Kelas Tipe 2 dan 3}

Ruang kelas Tipe 2 dan 3 memiliki kondisi yang sama terkait arah hadap, posisi dan ukuran ventilasi. Inlet ruang kelas Tipe 2 dan 3 memiliki tipe jendela ventilasi yang sama dengan kelas Tipe 1, akan tetapi dengan jumlah bukaan yang lebih banyak, mengingat ukuran ruangnya yang lebih besar. Sedangkan untuk outlet didisain dengan kombinasi jendela mati dan lubang-lubang ventilasi (gambar 13).

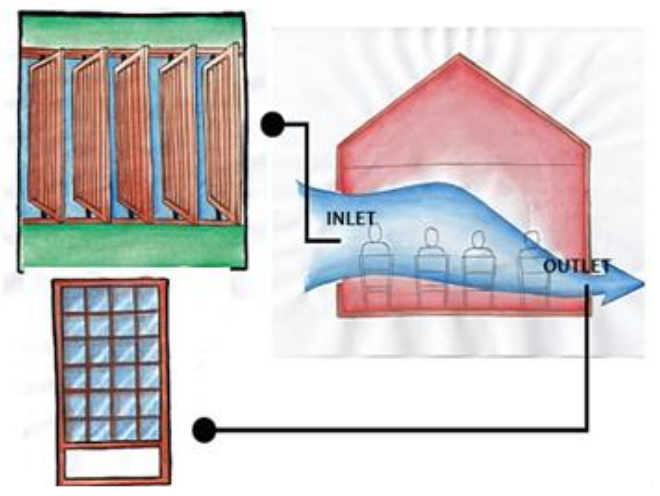

Gambar 13. Ilustrasi rekomendasi disain ventilasi silang di ruang kelas Tipe 2 dan Tipe 3 (sumber: hasil analisis, 2018)

\subsection{Simulasi Thermal Comfort Analysis}

Simulasi dicirikan dengan hasil keluaran data yang memiliki bentuk yang sama dalam konteks realitas. Simulasi mengacu pada hipotesa yang berbasis pada replica dari interaksi dinamis antar manipulasi faktor. (Juhana et al, 2009). Untuk menguji sekaligus memvalidasi keefektifan hasil rekomendasi disain yang telah dihasilkan, maka simulasi ecotect dengan jenis Thermal Comfort Analysis pun digunakan. Prinsipnya ialah dengan cara mengidentifikasi tingkat kenyamanan di tiap sisi ruang yang ditunjukkan dalam bentuk gradasi warna. Warna biru menunjukkan bahwa suhu ruangan relatif dingin, sedangkan warna kuning menunjukkan bahwa ruangan berada pada titik suhu terpanas. Sebaran warna tersebut akan disajikan dalam bentuk grafik suhu rata-rata ruang.

\section{Simulasi rekomendasi disain untuk kelas Tipe 1}

Pada gambar 14 menunjukkan perbedaan hasil simulasi distribusi kenyamanan termal antara kondisi eksisting dan rencana. Disain ruang dengan ventilasi eksisting memiliki kenyamanan termal yang kurang baik, yang ditandai oleh banyaknya titik-titik warna kuning. Sebaliknya pada simulasi ruang dengan bentuk ventilasi baru, menunjukkan kondisi kenyamanan termal yang cenderung lebih baik, dengan mayoritas ruang ditandai dengan titik-titik berwarna biru.

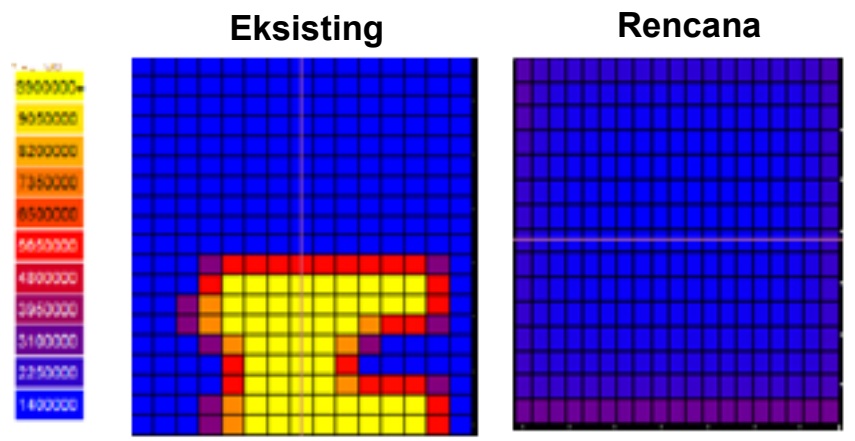

Gambar 14. Perbandingan hasil Thermal Comfort Analysis pada ruang kelas Tipe 1 antara eksisting dan rencana (sumber: hasil analisis, 2018)

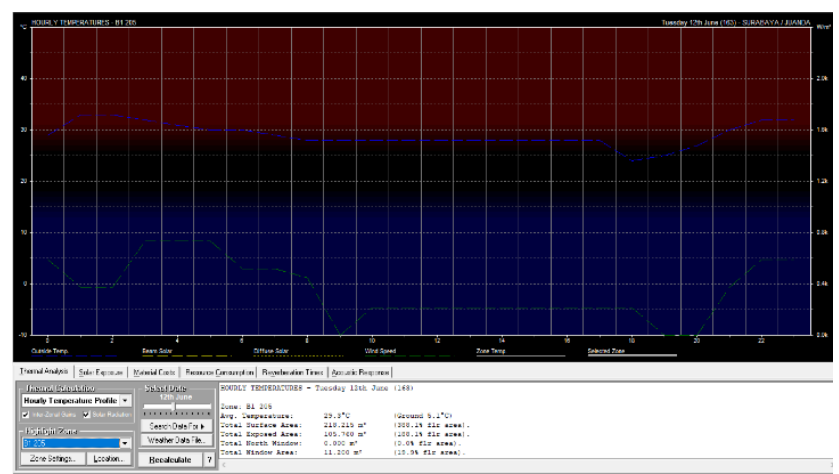

Gambar 15. Simulasi suhu ruang kelas Tipe 1 dengan disain ventilasi yang direkomendasikan (sumber: hasil analisis, 2018). 
Grafik simulasi suhu ruang pada gambar 15 juga telah menunjukkan bahwa setelah menggunakan disain ventilasi sesuai dengan yang direkomendasikan, ruang kelas Tipe 1 mengalami penurunan suhu hingga $29.3^{\circ} \mathrm{C}$, lebih rendah $2,7^{\circ} \mathrm{C}$ dari kondisi suhu eksisting.

\section{Simulasi rekomendasi disain untuk kelas Tipe 2}

Pada gambar 16 menunjukkan perbedaan hasil simulasi distribusi kenyamanan termal antara kondisi eksisting dan rencana untuk ruang kelas Tipe 2. Disain ruang dengan ventilasi eksisting memiliki kenyamanan termal yang cukup baik karena titik-titik suhu hangat (warna ungu) cenderung merata dan berbaur dengan suhu 'sejuk' (warna biru). Sedangkan pada simulasi ruang dengan bentuk ventilasi baru, menunjukkan kondisi kenyamanan termal yang relatif lebih baik, dengan ditandai titik yang mayoritas berwarna biru. Grafik simulasi suhu ruang pada gambar 17 menunjukkan bahwa setelah menggunakan rekomendasi disain unutk ruang kelas Tipe 2, suhu ruang mengalami penurunan sebesar $1,4^{\circ} \mathrm{C}$ dari suhu eksisting $\left(30,7^{\circ} \mathrm{C}\right)$ hingga menjadi $29,3^{\circ} \mathrm{C}$.

\section{Eksisting}
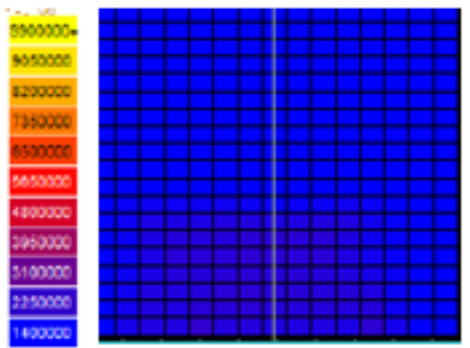

\section{Rencana}

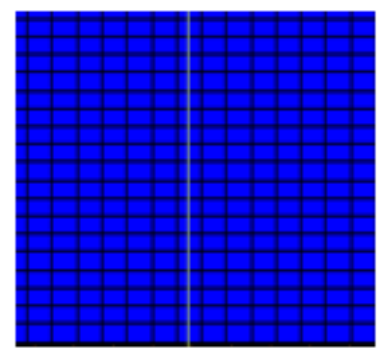

Gambar 16. Perbandingan hasil Thermal Comfort Analysis pada ruang kelas Tipe 2 antara eksisting dan rencana (sumber: hasil analisis, 2018)

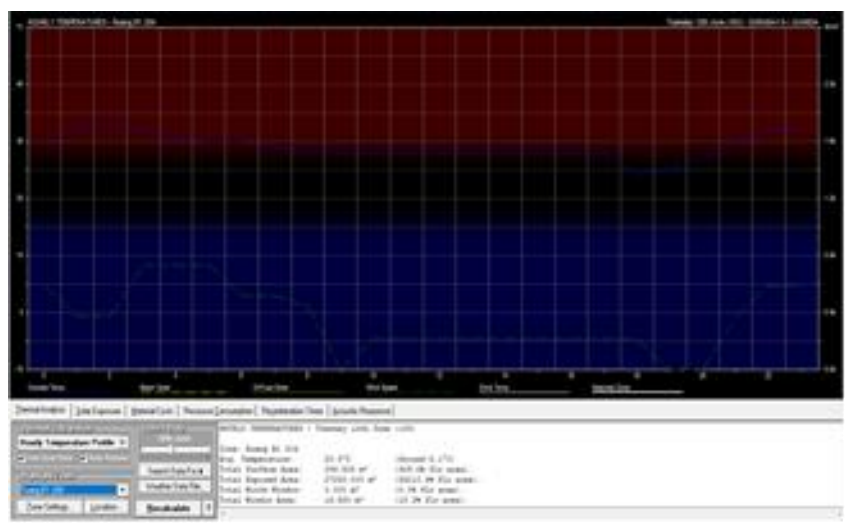

Gambar 17. Simulasi Suhu Ruang Kelas Tipe 2, dengan Desain Ventilasi yang Direkomendasikan (sumber: hasil analisis, 2018)

\section{Simulasi rekomendasi disain untuk kelas Tipe 3}

Pada gambar 18 menunjukkan perbedaan hasil simulasi distribusi kenyamanan termal antara kondisi eksisting dan rencana untuk ruang kelas Tipe 3.
Desain ruang dengan ventilasi eksisting memiliki kenyamanan termal yang kurang baik, yang ditandai oleh adanya warna kuning yang mendominasi seluruh sisi ruang. Sebaliknya pada simulasi ruang dengan bentuk ventilasi baru, menunjukkan kondisi kenyamanan termal yang baik, yang ditandai dengan titik-titik yang mayoritas berwarna biru. Grafik simulasi suhu ruang pada gambar 19 juga telah menunjukkan penurunan suhu sebesar $2,5^{\circ} \mathrm{C}$ pada ruang kelas Tipe 3 yang menggunakan disain ventilasi yang disarankan, dari suhu eksisting sebesar $30,7^{\circ} \mathrm{C}$ menjadi $28,2^{\circ} \mathrm{C}$.

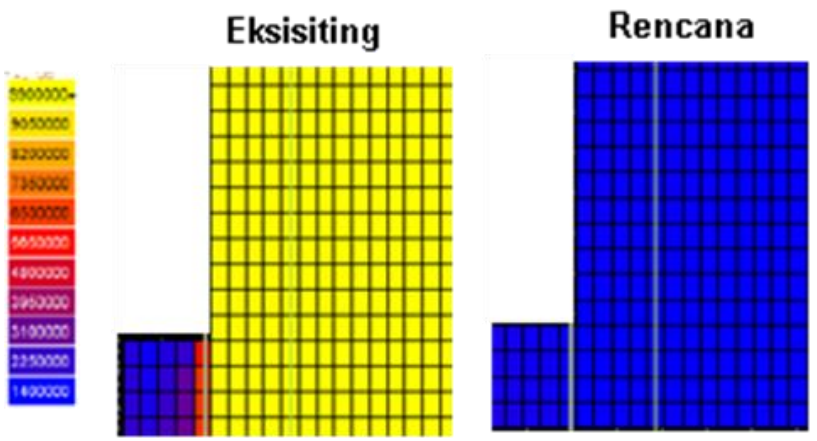

Gambar 18. Perbandingan hasil Thermal Comfort Analysis pada ruang kelas Tipe 3 antara eksisting dan rencana (sumber: hasil analisis, 2018)

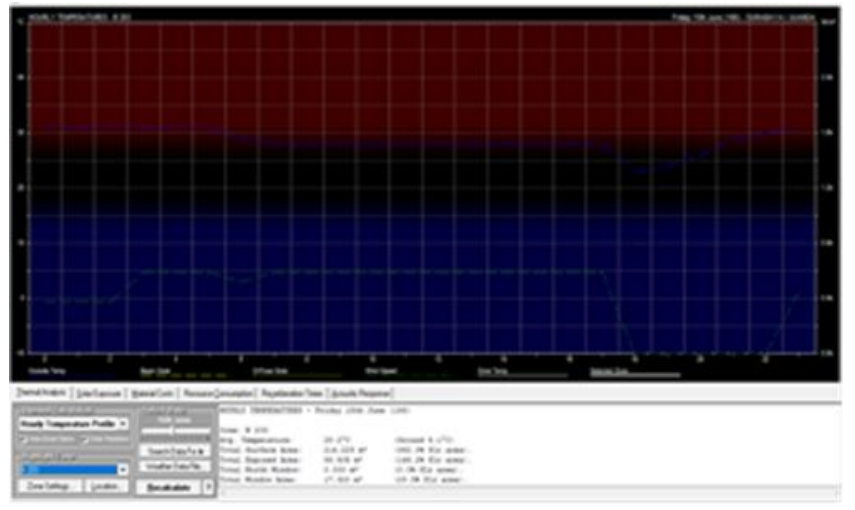

Gambar 19. Simulasi Suhu Ruang Kelas Tipe 3, dengan Desain Ventilasi yang Direkomendasikan (sumber: hasil analisis, 2018)

Penurunan suhu masih belum dapat dimaksimalkan hingga mencapai kenyamanan termal ideal, sebab arah orientasi aktifitas dalam ruang, menghambat kecepatan angin dari inlet untuk menghantarkan udara sejuk dan membuang udara panas, sebelum sampai ke outlet.

\section{KESIMPULAN}

Untuk mencapai kondisi yang ideal dari sebuah ruang kelas, dapat dicapai melalui kenyamanan termal. Kenyamanan termal dapat diupayakan jika ada sistem ventilasi silang dengan inlet dan outlet, yang mempertimbangkan ukuran, bentuk dan posisi dari ventilasi itu sendiri. Ventilasi sebesar $10 \%$ dari ukuran lantai, dengan jenis vertically pivoted adalah ventilasi 
terbaik yang dapat digunakan di beberapa ruang kelas di Fakultas Ushuluddin. Simulasi Thermal Comfort Analysis dengan piranti lunak ecotect menunjukkan bahwa rekomendasi disain ventilasi mampu menurunkan suhu ruang kelas hingga kisaran $1,4^{\circ} \mathrm{C}$ $2,7^{\circ} \mathrm{C}$. Penelitian lanjutan diperlukan untuk mengeksplorasi alternatif disain ventilasi lainnya yang mampu menurunkan suhu ruangan lebih besar lagi, dengan mempertimbangkan variabel-variabel lain yang dapat berpengaruh terhadap penurunan suhu ruang di dalam bangunan.

\section{DAFTAR PUSTAKA}

Badan Standarisasi Nasional. (2001). "SNI 03-65722001." Tata cara perancangan sistem ventilasi dan pengkondisian udara pada bangunan gedung, Badan Standarisasi Nasional, Indonesia.

Dora, Purnama Esa, and Poppy Firtatwentyna Nilasari. (2011). "Pemanfaatan Pencahayaan Alami pada Rumah Tinggal Tipe Townhouse di Surabaya." : 28-36.

Erna, Winansih, Antariksa, Surjono and Setyo Leksono Amin. (2015). "Thermal Comfort at The Street Corridor Around Public Places, Case Study AlunAlun Malang." Journal of Islamic Architecture : 177-182. http://dx.doi.org/10.18860/iia.v3i4.3102

Gratia, E., Bruyère, A., \& De Herde, A. (2004). How to use natural ventilation to cool narrow office buildings. Building and Environment, 39 (10): 1157-1170.
Juhana. (2009). "Teknik Simulasi dan Penelitian Kenyamanan Thermal Ruang Luar : Manfaat dan Kendalanya". Prosiding Seminar Nasional Penelitan Arsitektur Metode dan Penerapannya : Universitas Diponegoro : 37-44.

Latifah, N.L., Harry Perdana, Agung Prasetya, dan Oswald P.M. Siahaan. (2013). Kajian Kenymanan Termal Pada Bangunan Student Center ITENAS Bandung. Reka Karsa. Vol 1. No 1. https://doi.org/10.26760/rekakarsa.v1i1.43.

Lechner, Norbert. (2014). Heating, cooling, lighting: Sustainable design methods for architects. John wiley \& sons.

Mediastika, Christina E. (2004). "Desain Jendela Bangunan Domestik Untuk Mencapai Cooling Ventilation" Kasus uji: rumah sederhana luas $45 m 2$ di Yogyakarta." DIMENSI (Journal of Architecture and Built Environment) 30.1. https://doi.org/10.9744/dimensi.30.1.

Mendell, M.J., \& Heath, G.A. (2005). Do indoor pollutants and thermal conditions in schools influence student performance? A critical review of the literature. Indoor Air, 15, 27-52. https://doi.org/10.1111/j.16000668.2004.00320.x.

Tantasavasdi, C., Srebric, J., \& Chen, Q. (2001). Natural ventilation design for houses in Thailand. Energy and Buildings, 33(8), 815-824. DOI: 10.13140/RG.2.1.5178.1528

Winataputra, Udin S. (2008). "Materi dan Pembelajaran IPS. " Universitas Terbuka. Jakarta 